\title{
Mesencephalotomy, How I Do It: Analysis of 34 Cases
}

\section{Mesencefalotomia, como eu faço: análise de 34 casos}

\author{
Gustavo Veloso Lages ${ }^{1}$ José Oswaldo Oliveira Júnior ${ }^{20}$ \\ ${ }^{1}$ Pain Ambulatory, Hospital da Santa Casa de Montes Claros and of the \\ Hospital Dilson Godinho, Montes Claros, MG, Brazil \\ ${ }^{2}$ Central Pain and Stereotaxy Department, A. C. Camargo Cancer \\ Center, São Paulo, SP, Brazil \\ Address for correspondence José Oswaldo de Oliveira Júnior, Praça \\ Santo Agostinho, 70 cj 53C, São Paulo, SP, Brazil. CEP: 01533-070 \\ (e-mail: jo.oliveirajr@yahoo.com.br).
}

Arq Bras Neurocir 2019;38:227-235.

\begin{abstract}
Keywords

- pain

- functional neurosurgery

- facial pain

- cancer pain

- ablative procedure

\section{Resumo}

Palavras-chave

- dor

- neurocirurgia funcional

- dor facial

- dor oncológica

- cirurgia ablativa

The present paper aims to demystify the use of rostral mesencephalic reticulotomy (mesencephalotomy) in the treatment of chronic pain in cancer patients. A retrospective review of the medical records from the Central Pain and Stereotaxy Department of the A. C. Camargo Cancer Center, São Paulo, state of São Paulo, Brazil, between 2005 and 2012, was performed. Surgical indication was restricted to patients with cancer pain refractory to etiological and symptomatic treatments, $>2$ months of expected survival, preserved cognition, and absence of coagulation disorders, of systemic infection, and of intracranial hypertension. We have selected 34 patients, with an average follow-up of 9.4 months, an average age of 54.3 years-old, and an average follow-up time until death of 6.4 months. Lung cancer was the most frequent diagnosis. Satisfactory and immediate pain relief was achieved in $91 \%$ of the cases, and $83 \%$ of these patients had no relapses. Among the complications, ocular movement disorder was the most frequent, but often transient. Permanent disturbances occurred in $8.8 \%$ of the cases (diplopia, rubral tremor, and paresthesia). Compared to the pharmacological treatment, mesencephalotomy was economically feasible, more effective, and improved quality of life. According to the data presented, it can be concluded that mesencephalotomy is a viable procedure for cancer pain control in selected cases.

O presente artigo objetiva desmistificar o uso da reticulotomia rostral mesencefálica (mesencefalotomia) no tratamento da dor crônica em pacientes oncológicos. Foi realizada uma revisão retrospectiva dos prontuários dos pacientes submetidos a mesencefalotomia, entre 2005 e 2012, no Departamento da Central da Dor e Estereotaxia do A. C. Camargo Cancer Center, São Paulo, SP, Brasil. A indicação cirúrgica foi restrita aos portadores de dor oncológica refratária aos tratamentos etiológicos e sintomáticos, com expectativa de sobrevida $>2$ meses, cognição preservada, ausência de distúrbios de coagulação, de infecção sistêmica, e de hipertensão intracraniana. Foram selecionados 34 pacientes, com seguimento médio de 9,4 meses, idade média de 54,3 anos, tempo médio de seguimento
\end{abstract}

(D) José Oswaldo de Oliveira Júnior's ORCID is https://orcid.org/00000002-7130-8171.

received

June 8,2016

accepted

August 30, 2016
DOI https://doi.org/

10.1055/s-0036-1594260. ISSN 0103-5355.
Copyright @ 2019 by Thieme Revinter

Publicações Ltda, Rio de Janeiro, Brazil
License terms

(c) (1) $\ominus$ (5) 
até o óbito de 6,4 meses. O câncer de pulmão foi o diagnóstico mais frequente. Houve alívio satisfatório e imediato da dor em $91 \%$ dos casos, e $83 \%$ não tiveram recidivas. Dentre as complicações, o distúrbio da movimentação ocular foi o mais frequente, sendo em sua maioria de caráter transitório. Distúrbios permanentes ocorreram em 8,8\% dos casos (diplopia, tremor rubral, e parestesia). No que se refere à comparação com o tratamento farmacológico, o procedimento mostrou-se economicamente viável, mais efetivo, além de fornecer qualidade de vida. Com os dados apresentados, foi permitido concluir que a mesencefalotomia é um procedimento viável para o controle da dor oncológica.

\section{Introduction}

The $20^{\text {th }}$ century and the beginning of the $21^{\text {st }}$ century witnessed a progressive increase in the longevity of the world population. People afflicted by several diseases, whose diagnoses represented true condemnations and prophecies of suffering and death, came to survive. It was not long before the increased survival had an additional call for quality of life. It was not enough to stay alive, but to live well. There is no successful strategy to offer quality of life without adequate relief from a possible painful discomfort. There have been developments in etiological and symptomatic treatment throughout medicine, but despite this auspicious advancement, many people still suffer from pain refractory to analgesic pharmacotherapy and to therapeutic methods for underlying diseases, especially in oncology. Approximately $5 \%$ of people who complain of pain require a symptomatic interventional treatment. ${ }^{1}$

Several procedures have been used over the years, and new surgical techniques have been developed based on the increased anatomical and physiological knowledge of pain pathways. ${ }^{2}$

Despite its long history and efficacy, the use of destructive (or ablative) techniques has diminished in modern practice, being replaced by new conservative and nondestructive interventional approaches, such as the implantation of neurostimulation systems and the release of analgesic drugs into the central nervous system (CNS). ${ }^{3}$

\section{History}

In 1878 , a patient with a gunshot wound injury reported loss of pain sensation and preserved touch awareness in one side of the body. Around the same time, a $2^{\text {nd }}$ patient reported a similar loss of painful sensitivity. Necropsies revealed the anatomical involvement of the spinal cord anterolateral columns contralateral to the sensory alteration, which was traumatic in the $1^{\text {st }}$ case and associated with a tuberculoma in the $2^{\text {nd }}$.

Spiller, in 1905, based on both reports, considered that the pain pathway preferably included lateral spinothalamic tracts. Seven years later, an open cordotomy was successfully performed by Martin; moreover, in 1963, it was successfully performed through a percutaneous approach by Mullan. It was not long before neurosurgeons identified the limits and risks of cordotomy in obtaining analgesia of more cranial pains from thoracic, brachial, and cephalic territories. ${ }^{4-9}$

Created and first performed by Dogliotti in 1938, the lateral spinothalamic tract injury to control refractory oncologic pain affecting areas above the nipple gained strength and recognition with Walkerin, in 1942. His studies showed that the posterior portion of the mesencephalon would be the safest and most effective region for approaching this tract, contrary to his predecessor, who advocated a pontine access to the target. ${ }^{3}$

The rostral mesencephalic reticulotomy (RMM) by stereotaxy, also known as mesencephalotomy, was first used in the treatment of cancer-induced pain in 1953, by the pioneers Spiegel et al. ${ }^{1}$

The procedure is based on the interruption of the spinothalamic tract, of the 5th thalamic tract, and of a portion of the reticular formation in the rostral region of the mesencephalic tegmentum, modifying the sensation of pain. ${ }^{1}$

\section{Objectives}

To demystify the unfounded aversion to an ablative surgical technique, known as mesencephalotomy, based on relatively high rates of permanent complications reported in early publications.

This objective will be achieved by comparing the results obtained in an extensive literature review about this procedure with those observed in a series of patients from the Department of Pain Management, Functional Surgery and Palliative Care of the Celestino Bourroul Cancer School of the Fundação Antônio Prudente (FAP, in the Portuguese acronym), São Paulo, state of São Paulo, Brazil, between 2005 and 2012.

\section{Indication}

Surgical indication was restricted to patients with cancer pain that was refractory to etiological and symptomatic treatments (multidisciplinary and multiprofessional), predominantly lateral, affecting the head, the neck, the upper chest, and the upper limbs. The patients should have $>2$ months of expected survival and preserved cognition; moreover, they should not present coagulation disorders, active systemic infection, nor signs or symptoms of intracranial hypertension. ${ }^{2,10}$ 


\section{Surgical Technique}

The RMM target is 5.0 to $5.5 \mathrm{~mm}$ posterior to the posterior commissure, or 18 to $18.5 \mathrm{~mm}$ posterior to the intercommissural midpoint (at the intercommissural line); 4.5 to $5.0 \mathrm{~mm}$ below the intermural plane, perpendicularly; and 5.0 to $10.0 \mathrm{~mm}$ lateral to the midline, passing through the middle of the $3^{\text {rd }}$ ventricle and the Sylvius aqueduct, contralateral to the refractory pain complaint. ${ }^{1,2,5,6,11}$ A simplification used in practice is the adoption of the calculation of the $1^{\text {st }}$ coordinates - $5 \mathrm{~mm}$ posterior, $5 \mathrm{~mm}$ inferior, and $5 \mathrm{~mm}$ lateral to the midpoint of the posterior commissure - and then the performance of possible corrections from macrostimulation(-Fig. 1).

The experience of the team with target identification in the treatment of movement disorders and of refractory pain has allowed us to note that, depending on the angle between the floor line of the $4^{\text {th }}$ ventricle and the intercommissural line, the mesencephalotomy target may travel anteriorly and vary from 14 to $19 \mathrm{~mm}$ from the intercommissural point.

\section{Stimulation and Somatotopic Arrangement}

Knowledge on the functional anatomy of the midbrain especially from structures adjacent to the lateral spinothalamic tract (the periaqueductal gray matter, the ascending reticular activating substance, the medial lemniscus, the upper and lower colliculus, the nucleus rubrus, and the medial longitudinal fasciculus) - is essential to perform this procedure. Spiegel et $\mathrm{al}^{1}$ reported a considerable incidence of painful anesthesia following RMM. They attributed this complication to the accidental injury of the medial lemniscus, which runs a little ventral and medial to the spinothalamic tract. ${ }^{1}$ The medial lemniscus is an important discriminative pathway and plays a prominent role in the balance and function of the endogenous and pain suppressive system. Its transoperative stimulation causes discomfort in shocks, formication, and numbness in the contralateral hemibody, while stimulation of the lateral spinothalamic tract evokes thermal sensations, and, rarely, pain. ${ }^{1,12}$

-Fig. 2 shows the interrelationships between the various nuclei, the ascending reticular activating substance, and the

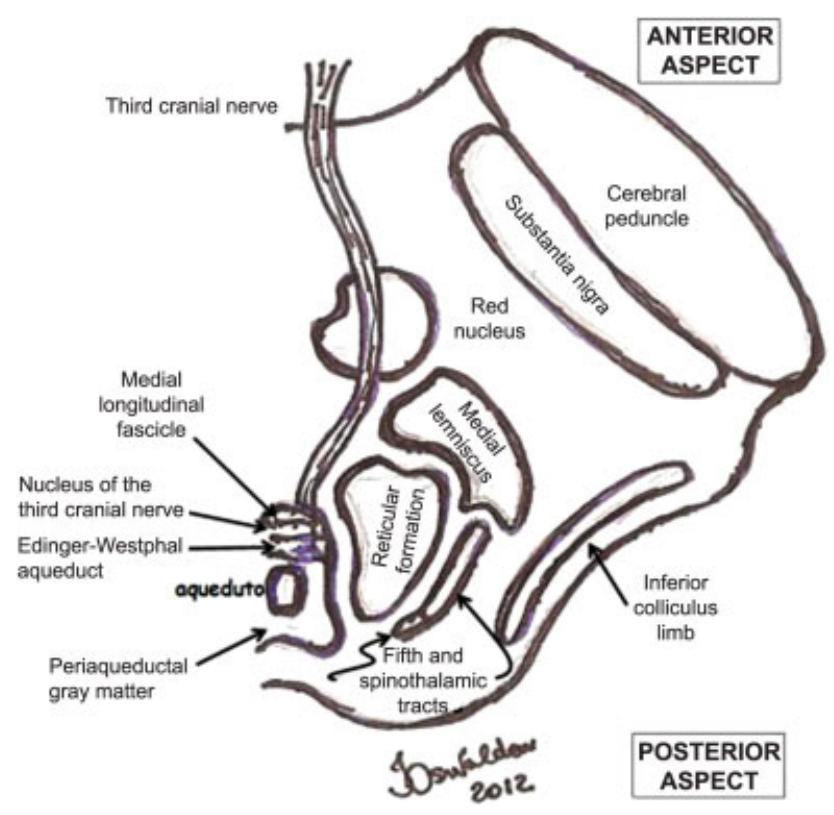

Fig. 2 Drawing of the midbrain at the inferior colliculus level, schematically illustrating the relationship between the nuclei.

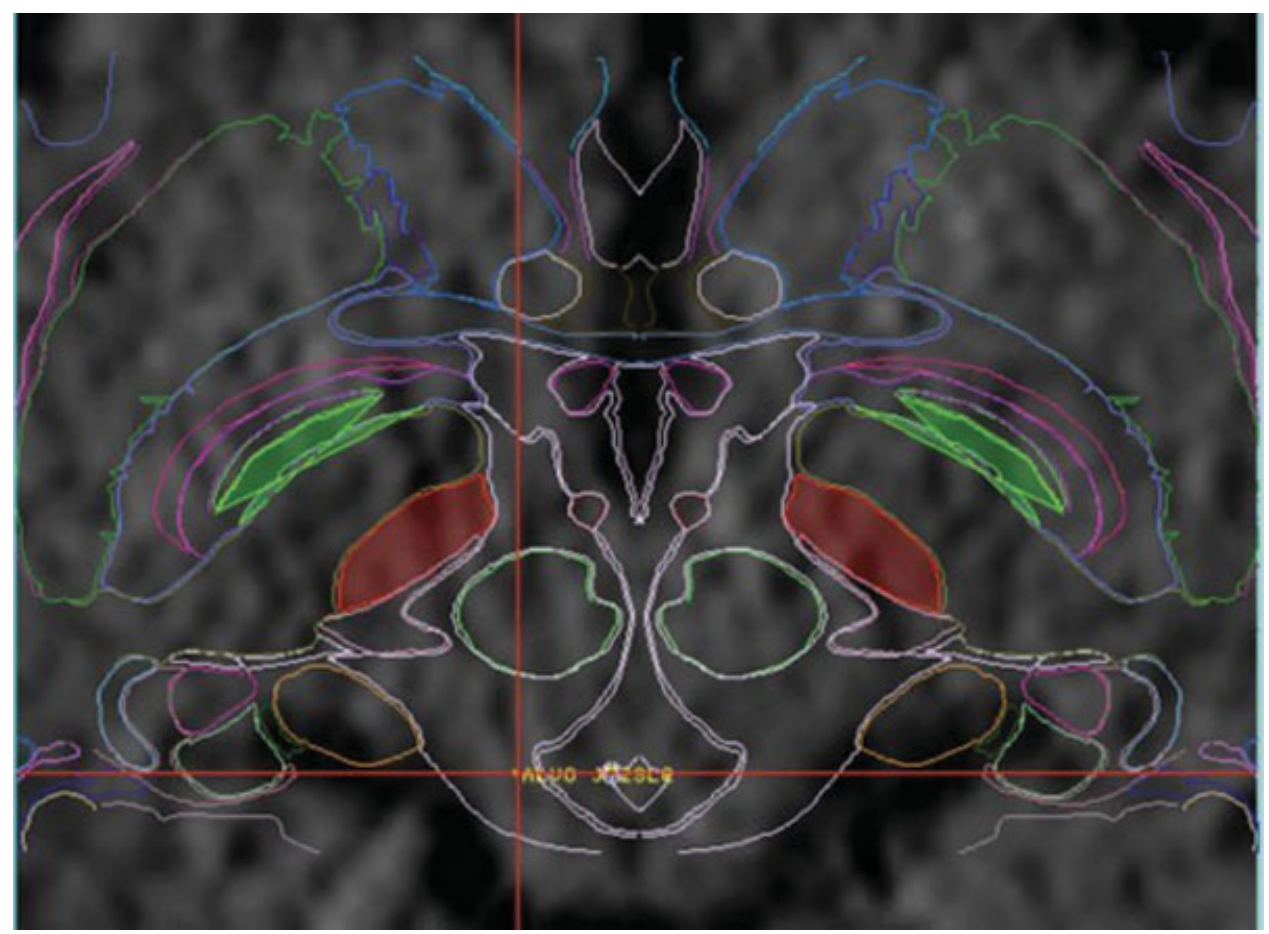

Fig. 1 Surgical planning showing a tomography image virtually fused with the Schaltenbrand atlas, in a thin section of the mesencephalic region, at the superior colliculus level. 
Table 1 Relationship between stimuli and coordinates with the expected effects

\begin{tabular}{|c|c|c|c|c|c|c|c|}
\hline Level & $\begin{array}{l}\text { Distance } \\
\text { (midline) }\end{array}$ & $\begin{array}{l}\text { Subjective } \\
\text { sensation }\end{array}$ & Referred site & Motor & Autonomic & Affective & Other \\
\hline $\begin{array}{l}\text { Posterior } \\
\text { commissure } \\
\text { (cranial) }\end{array}$ & $0-5 \mathrm{~mm}$ & Vibration & $\begin{array}{l}\text { Center of the } \\
\text { face, head } \\
\text { and chest }\end{array}$ & $\begin{array}{l}\text { Eyelid } \\
\text { closure, } \\
\text { grimacing } \\
\text { face, eye and } \\
\text { cranial } \\
\text { movement }\end{array}$ & None & $\begin{array}{l}\text { Intense } \\
\text { response, } \\
\text { fear and } \\
\text { panic }\end{array}$ & $\begin{array}{l}\text { Hyperventi- } \\
\text { lation, deep } \\
\text { or fast } \\
\text { breathing }\end{array}$ \\
\hline $\begin{array}{l}\text { Posterior } \\
\text { commissure } \\
\text { (cranial) }\end{array}$ & $5-10 \mathrm{~mm}$ & $\begin{array}{l}\text { Heat, pain } \\
\text { and burning } \\
\text { sensation }\end{array}$ & $\begin{array}{l}\text { Contralateral } \\
\text { face, upper } \\
\text { limb and } \\
\text { chest }\end{array}$ & $\begin{array}{l}\text { Partial eyelid } \\
\text { closure }\end{array}$ & $\begin{array}{l}\text { Contralateral } \\
\text { piloerection } \\
\text { and sweating }\end{array}$ & Fright & Nausea \\
\hline $\begin{array}{l}\text { Superior } \\
\text { colliculus } \\
\text { (medial) }\end{array}$ & $0-5 \mathrm{~mm}$ & $\begin{array}{l}\text { Burning, } \\
\text { cold, } \\
\text { numbness }\end{array}$ & $\begin{array}{l}\text { Head, nose, } \\
\text { eyes, mouth, } \\
\text { chest and } \\
\text { upper limb }\end{array}$ & $\begin{array}{l}\text { Eye } \\
\text { movement, } \\
\text { increased } \\
\text { palpebral } \\
\text { opening }\end{array}$ & $\begin{array}{l}\text { Pulse } \\
\text { frequency } \\
\text { increase, } \\
\text { breathing } \\
\text { inhibition }\end{array}$ & $\begin{array}{l}\text { Fright } \\
\text { (strong } \\
\text { response) }\end{array}$ & $\begin{array}{l}\text { Vocalization, } \\
\text { speech } \\
\text { impairment }\end{array}$ \\
\hline $\begin{array}{l}\text { Superior } \\
\text { colliculus } \\
\text { (medial) }\end{array}$ & $5-10 \mathrm{~mm}$ & $\begin{array}{l}\text { Pain, } \\
\text { burning, } \\
\text { cold, } \\
\text { shivering } \\
\text { sensation }\end{array}$ & $\begin{array}{l}\text { Face, chest, } \\
\text { upper limb, } \\
\text { trunk }\end{array}$ & $\begin{array}{l}\text { Eyelid } \\
\text { closure }\end{array}$ & & Intense pain & $\begin{array}{l}\text { Post- } \\
\text { discharge } \\
\text { pattern at } \\
\text { EEG }\end{array}$ \\
\hline $\begin{array}{l}\text { Inferior } \\
\text { colliculus } \\
\text { (caudal) }\end{array}$ & $0-5 \mathrm{~mm}$ & $\begin{array}{l}\text { Pain, heat, } \\
\text { funny feeling }\end{array}$ & $\begin{array}{l}\text { Head, face, } \\
\text { oral cavity } \\
\text { and lower } \\
\text { limb }\end{array}$ & $\begin{array}{l}\text { Increased } \\
\text { palpebral } \\
\text { opening, eye } \\
\text { oscillating } \\
\text { conver- } \\
\text { gence, } \\
\text { ipsilateral } \\
\text { facial } \\
\text { contraction }\end{array}$ & $\begin{array}{l}\text { Face and } \\
\text { neck } \\
\text { redness, } \\
\text { piloerection } \\
\text { in upper limb } \\
\text { and trunk }\end{array}$ & $\begin{array}{l}\text { Fright, } \\
\text { strong } \\
\text { response }\end{array}$ & $\begin{array}{l}\text { Central pain, } \\
\text { activation, } \\
\text { sighed } \\
\text { breath }\end{array}$ \\
\hline $\begin{array}{l}\text { Inferior } \\
\text { colliculus } \\
\text { (caudal) }\end{array}$ & $5-10 \mathrm{~mm}$ & Pain, burning & $\begin{array}{l}\text { Upper limb, } \\
\text { face and } \\
\text { shoulder }\end{array}$ & $\begin{array}{l}\text { Eye } \\
\text { movement }\end{array}$ & & Crying & $\begin{array}{l}\text { Postdi- } \\
\text { scharge } \\
\text { pattern at } \\
\text { EEG }\end{array}$ \\
\hline
\end{tabular}

Abbreviation: EEG, electroencephalogram.

multiple tracts found in this specific part of the mesencephalic region.

- Table 1 summarizes the different sensations obtained with stimulation $>60 \mathrm{~Hz}$ in 3 midbrain depths (heights) (identifying the most representative structure from each level). ${ }^{4}$

-Figs. 3 and 4 represent the ideal site for lesion performance, as well as the involved structures and body segment.

\section{Data Analysis}

After approval by the ethics committee, 34 medical records from patients submitted to RMM in the Department of Pain Management, Functional Surgery and Palliative Care of the Celestino Bourroul Cancer School of FAP between 2005 and 2012 were analyzed, as shown in -Table 2.

All of the patients had cancer, except for two cases of aggressive neurofibromatosis that were refractory to clinical and surgical treatment.

The statistical analysis was performed at the SOFA Statistics software for Mac, Version. 1.3.

The mean age of the patients was 54.3 years old (standard deviation [SD]: 13.3 years old). The mean fol- low-up time was 9.4 months (SD: 17.15 months), but, excluding the $1^{\text {st }}$ case of the series, which was a patient with neurofibromatosis surviving to this date, this average falls to 6 months.

The rate of loss to follow-up was relatively high, of $32.4 \%$. However, because these are cancer patients and A. C. Camargo Hospital is a national reference hospital, having many patients from all over the country, this loss is understandable, since the mean time until the death of the patients submitted to the procedure was of 6.4 months.

Lung cancer was the most frequent diagnosis (-Fig. 5). Squamous cell carcinoma (SCC) was also very prevalent, affecting predominantly the face, the neck, and the trunk.

The improvement index was based on the report of the patients, mainly using a numerical verbal scale; however, reports of family members, medication reduction, and psychosocial aspects were also considered. -Fig. 6 illustrates the percentage of improvement in the intensity of the postoperative pain.

Patients who were lost to follow-up were excluded from the analysis of pain recurrence (-Fig. 7 ). 


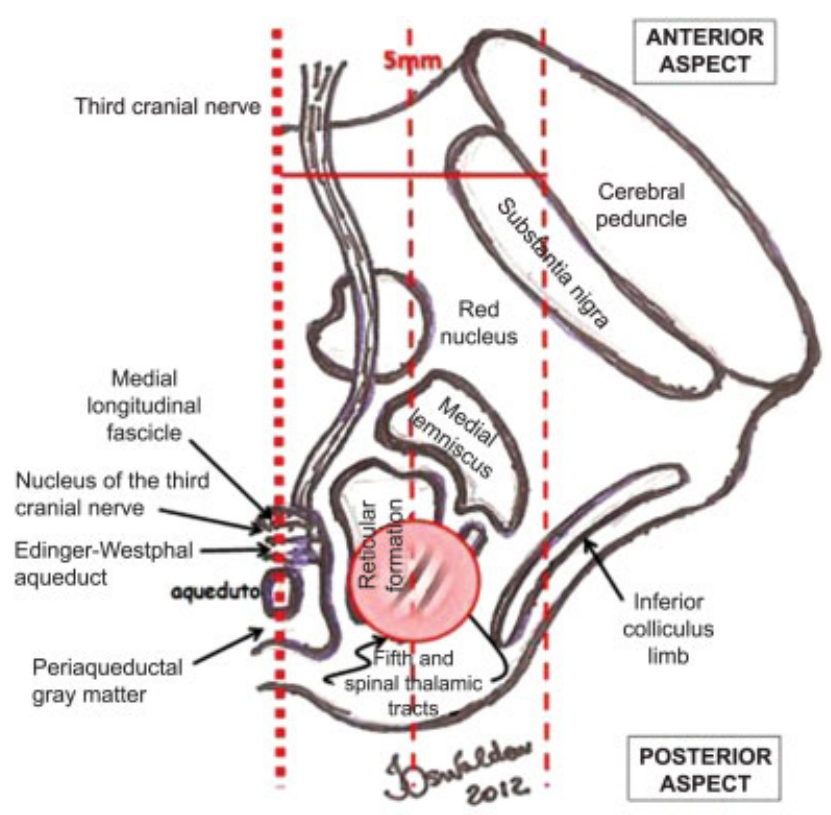

Fig. 3 Representative drawing of the ideal lesion site in mesencephalotomy

Among the postoperative complications (-Fig. 8), ocular movement disorder was the most present; however, it is important to note that most cases were transient. Permanent disturbances occurred in only 3 patients (8.8\%), who evolved, respectively, with diplopia, rubral tremor, and paresthesia.

\section{Discussion}

Stereotactic RMM, also known as mesencephalotomy, was first used in the treatment of cancer-induced pain in 1953 by
Spiegel et al, but was abandoned for a long time due to the large number of associated complications. ${ }^{1}$

The procedure is based on the interruption of the spinothalamic and of the $5^{\text {th }}$ thalamic tracts at the rostral portion of the mesencephalic tegmentum, interfering in the main pain conduction pathway. 1

The procedure provides hypoalgesia, not analgesia, in the upper portion of the contralateral hemibody (hemiface and upper limbs), with a frequent effect on the lower limbs. ${ }^{1}$

The path traveled by the pain stimulus begins in the peripheral nociceptors. These nociceptors generate impulses that are transmitted along A-delta and C-fibers to the cell bodies of the spinal ganglion, where they synapse mainly with the cells of the I, II and V layers from the dorsal horns. The two main ascending pathways that carry pain sensation in the dorsal horn are the lateral or neospinothalamic pathway and the medial or paleospinothalamic pathway. ${ }^{12-15}$

Primarily from finely myelinated fibroids, the oligosynaptic neospinothalamic tract is responsible for pain localization and intensity through the discriminative somatosensory pathway. $^{16}$

The paleospinothalamic pathway is polysynaptic and originated mainly by fiber $C$ stimuli; it is involved in the affective dimension of pain, and it is not related to cortical engrams. The data set undergoes upward dichotomy transmitted by the lateral, anterior and reticular spinothalamic tracts. $^{16}$

Most painful fibers that constitute the spinothalamic tract are formed by axons from second order sensory neurons that cross the spinal cord soon after receiving synapses from peripheral pseudounipolar neurons.

The cephalic (cranial or rostral) continuation of the medullary gray matter (dorsal horn) is represented by the

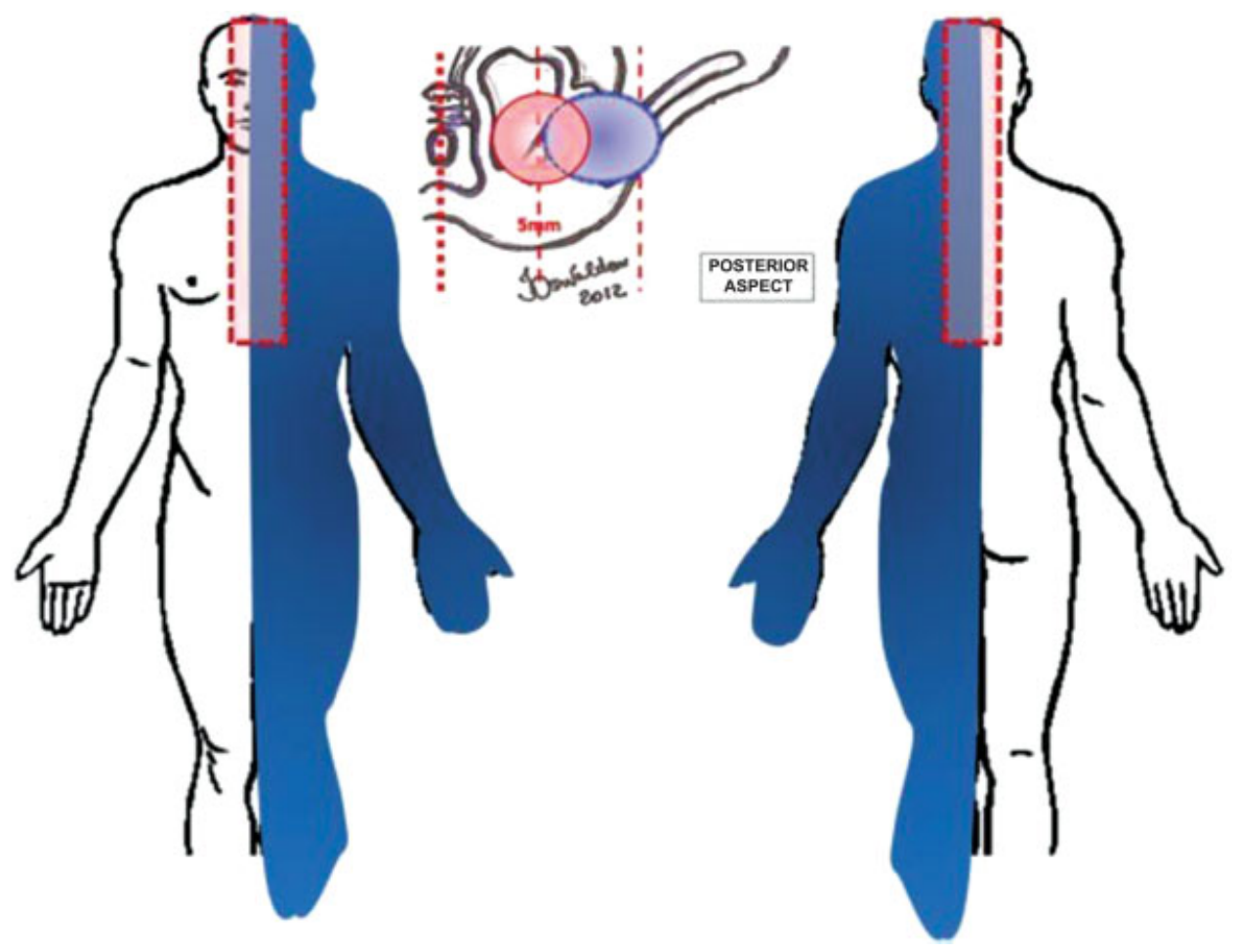

Fig. 4 Representation of the lesion and anatomical correlation. 
232 Mesencephalotomy, How I Do It Lages et al.

Table 2 Analysis of the outcomes from the 34 patients who underwent mesencephalotomy

\begin{tabular}{|c|c|c|c|c|c|}
\hline Patient & Age & Diagnosis & Follow-up & Outcome & Complication \\
\hline P.H.M. & 28 & Neurofibromatosis & 7 years & $60 \%$ pain improvement & None \\
\hline I. T. C. & 56 & Breast cancer & Lost to follow-up & $\begin{array}{l}100 \% \text { pain improvement } \\
\text { at IPP }\end{array}$ & $\begin{array}{l}\text { Somnolence and } \\
\text { confusion }\end{array}$ \\
\hline A. A. M. & 28 & Leiomyosarcoma & Lost to follow-up & $\begin{array}{l}>80 \% \text { pain improvement } \\
\text { at IPP }\end{array}$ & $\begin{array}{l}\text { Intense somnolence and } \\
\text { reversible diplopia }\end{array}$ \\
\hline M. A. G. & 59 & Lung cancer & Death in 6 months & $\begin{array}{l}\text { 100\% pain improvement } \\
\text { until death }\end{array}$ & None \\
\hline A. G. M. & 64 & Lymphoma & Death in 10 months & $\begin{array}{l}\text { Pain improvement until } \\
\text { last month of life }\end{array}$ & None \\
\hline M. A. B. & 65 & SCC & Death in 3 months & $100 \%$ improvement & $\begin{array}{l}\text { Reversible somnolence } \\
\text { and diplopia }\end{array}$ \\
\hline J. M. G. & 48 & SCC & Lost to follow-up & $\begin{array}{l}100 \% \text { pain improvement } \\
\text { at IPP }\end{array}$ & $\begin{array}{l}\text { Transient diplopia and } \\
\text { somnolence }\end{array}$ \\
\hline K. Y. & 63 & Colon cancer & Lost at follow-up & $100 \%$ improvement & $\begin{array}{l}\text { Transient diplopia and } \\
\text { somnolence }\end{array}$ \\
\hline A. T. M. & 41 & SCC & & $80 \%$ pain improvement & Transient diplopia \\
\hline W. A. H. & 52 & Parotid cancer & Death in 4 months & $100 \%$ improvement & None \\
\hline L. C. H. & 59 & Parotid cancer & Lost to follow-up & $100 \%$ pain improvement & $\begin{array}{l}\text { Transient diplopia } \\
\text { somnolence, and } \\
\text { persistent hand } \\
\text { paresthesia }\end{array}$ \\
\hline L. A. F. & 59 & Lung cancer & Death in 2 years & $>80 \%$ pain improvement & None \\
\hline N.B.C.F.P. & 62 & Lung cancer & Death in 3 months & $>80 \%$ improvement & None \\
\hline F. S. S. B. & 49 & Lung cancer & Lost at follow-up & $\begin{array}{l}100 \% \text { pain improvement } \\
\text { at IPP }\end{array}$ & Vomiting and diplopia \\
\hline M. L. P. A. & 49 & Breast cancer & Death in 1 year & $\begin{array}{l}100 \% \text { improvement at IPP, } \\
30 \% \text { improvement after } \\
4 \text { months }\end{array}$ & $\begin{array}{l}\text { Persistent diplopia and } \\
\text { dysesthesia }\end{array}$ \\
\hline A. J. R. & 55 & Kidney cancer & 6 months & $100 \%$ pain improvement & Rubral tremor \\
\hline M. F. G. C. & 51 & Lung cancer & Death in 3 months & $\begin{array}{l}100 \% \text { improvement at } \\
\text { IPP, > } 80 \% \text { improvement } \\
\text { at death }\end{array}$ & None \\
\hline J. C. F. O. & 38 & $\begin{array}{l}\text { Trapezoid } \\
\text { liposarcoma }\end{array}$ & $\begin{array}{l}\text { Death in } 1 \text { year and } \\
2 \text { months }\end{array}$ & $100 \%$ pain improvement & $\begin{array}{l}\text { Reversible diplopia and } \\
\text { hypersomnia }\end{array}$ \\
\hline W. V. F. & 61 & Lung cancer & Lost to follow-up & $50 \%$ pain improvement & Diplopia \\
\hline E. J. F. & 66 & SCC & Lost to follow-up & $>80 \%$ pain improvement & $\begin{array}{l}\text { Left arm numbness } \\
\text { resolved in } 4 \text { weeks }\end{array}$ \\
\hline L. F. F. Z. & 49 & Lung cancer & Death in 6 months & $100 \%$ improvement at IPP & $\begin{array}{l}\text { Reversible diplopia and } \\
\text { hypersomnia }\end{array}$ \\
\hline V. A. A. M. & 46 & Breast cancer & Death in 2 months & $100 \%$ pain improvement & Hypersomnia \\
\hline \multirow[t]{2}{*}{ A. A. O. } & 48 & Lung cancer & Death in 1 year & $100 \%$ improvement at IPP & $\begin{array}{l}\text { Multidirectional } \\
\text { nystagmus }\end{array}$ \\
\hline & & & & $\begin{array}{l}80 \% \text { improvement until } \\
\text { death }\end{array}$ & \\
\hline R. B. A. & 47 & Lung cancer & Death in 3 months & $100 \%$ pain improvement & Hypersomnia \\
\hline M. S. L. & 42 & SCC & Death in 1 months & $\begin{array}{l}80 \% \text { improvement until } \\
\text { death }\end{array}$ & None \\
\hline A. J. R. & 71 & Lung cancer & Death in 2 months & 100\% improvement & Palpebral ptosis \\
\hline S. A. S. & 54 & SCC & Death in 7 months & $100 \%$ improvement & None \\
\hline
\end{tabular}


Table 2 (Continued)

\begin{tabular}{|c|c|c|c|c|c|}
\hline Patient & Age & Diagnosis & Follow-up & Outcome & Complication \\
\hline L. G. A. P. & 63 & $\begin{array}{l}\text { Nasopharyngeal } \\
\text { SCC }\end{array}$ & Death in 2 months & $\begin{array}{l}\text { Procedure not concluded } \\
\text { due to intraoperative } \\
\text { respiratory disorder }\end{array}$ & $\begin{array}{l}\text { Procedure not concluded } \\
\text { due to intraoperative } \\
\text { respiratory disorder }\end{array}$ \\
\hline C. M. M. & 51 & Parotid cancer & Lost to follow-up & $\begin{array}{l}\text { No improvement: } \\
\text { unsuccessful } \\
\text { cingulotomy, } \\
\text { unsuccessful pump } \\
\text { implant }\end{array}$ & None \\
\hline M. A. T. L. & 75 & SCC & Death in 1 month & $>50 \%$ improvement & Nausea and vomiting \\
\hline R. M. S. & 26 & Neuro-bromatosis & 8 months & $>80 \%$ pain improvement & None \\
\hline M. A. A. & 86 & Lung cancer & $\begin{array}{l}\text { Lost to follow-up } \\
\text { after } 1 \text { month }\end{array}$ & $\begin{array}{l}100 \% \text { improvement no } \\
\text { POI, < than } 50 \% \\
\text { improvement after } \\
1 \text { week }\end{array}$ & $\begin{array}{l}\text { Surgical wound infection, } \\
\text { nystagmus, eye } \\
\text { movement deficit }\end{array}$ \\
\hline N. X. & 71 & Lung cancer & 5 months & $>80 \%$ improvement & Eye movement deficit \\
\hline N. M. B. & 65 & Lung cancer & 3 months & $>50 \%$ pain improvement & None \\
\hline
\end{tabular}

Abbreviations: IPP, immediate postoperative period; SCC, squamous cell carcinoma.

spinal trigeminal nucleus, which mediates the painful sensation of a portion of the cephalic segment. The spinal trigeminal nucleus projects to the posteromedial ventral nucleus (PVM) of the thalamus, to the intralaminar nuclei, and to the reticular formation. The thalamic projection of these tracts lies in the ventrocaudal (Vc) nucleus; The

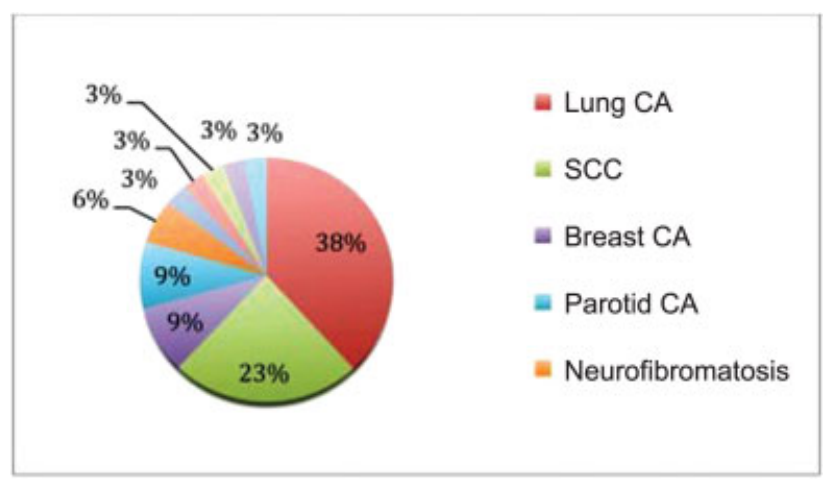

Fig. 5 Preoperative diagnosis of patients submitted to the mesencephalotomy. Abbreviations: CA, cancer; SCC, squamous cell carcinoma.

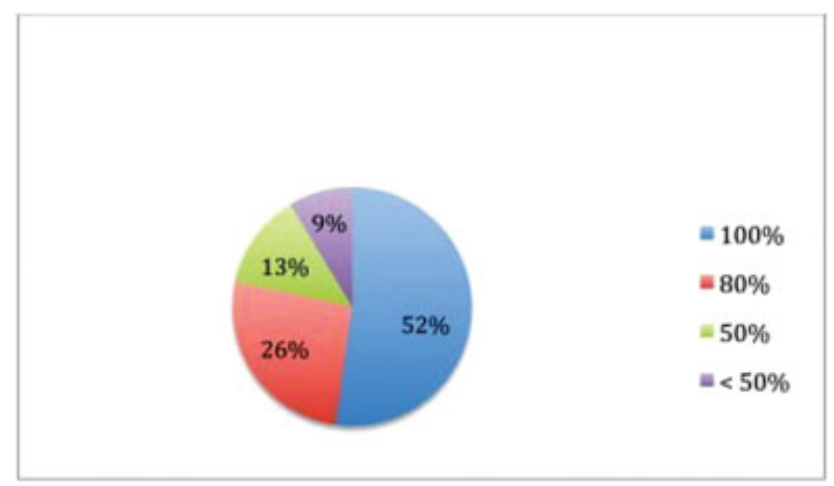

Fig. 6 Visual analog scale at the immediate postoperative period. cephalic afferent territory is represented in the most medial portion of the Vc (PVM), while the afferent territory for the rest of the body is in the most lateral portion (ventral posterolateral [VPL]). ${ }^{12}$

The medial pathway has been implicated in the affective component of pain. This pathway consists of the innermost

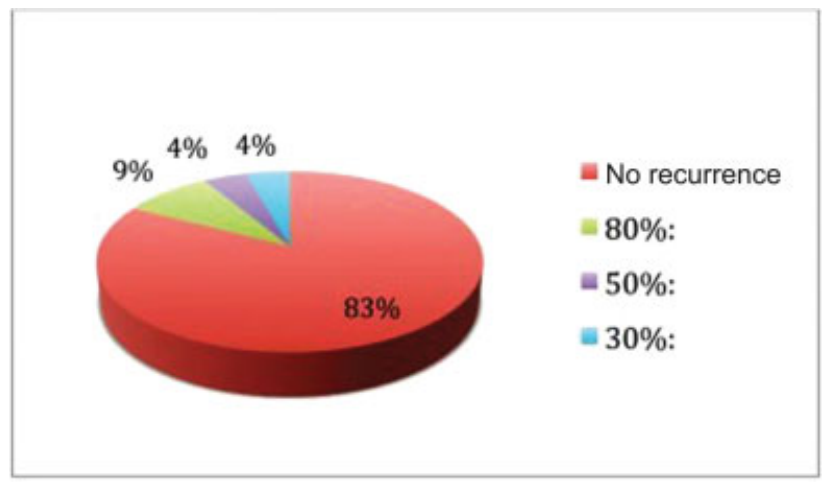

Fig. 7 Percentage of pain recurrence.

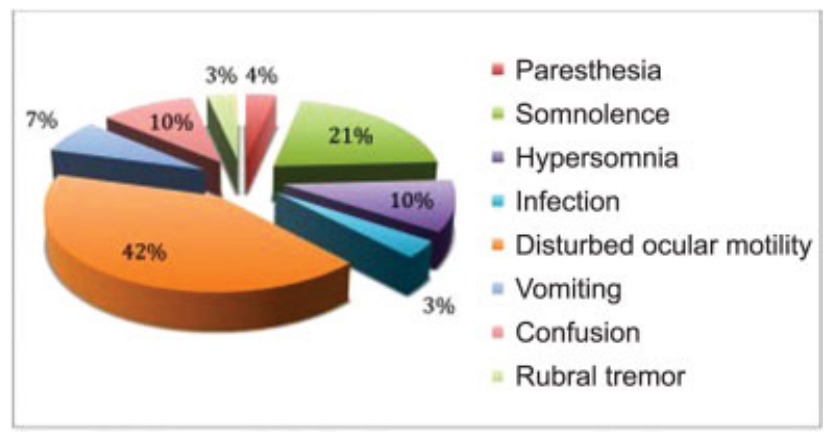

Fig. 8 Postoperative complications. 
portions of the spinothalamic and spinoreticular tracts. The medial pathway contains projections for the reticular formation of the brainstem, of the periaqueductal gray matter, of the hypothalamus, of the medial thalamic nuclei (e.g., parafascicular [Pf] and centrolateral $[\mathrm{Cl}]$ ), and of the anterior limbic structures, such as the anterior cingulate and the insular cortex. ${ }^{12}$

Since 1937, when Papez presented the hypothesis of a reverberant circuit encompassing a large portion of the limbic system, it was shown that these structures were responsible for the memory of pain and for the suffering associated with it. ${ }^{17-19}$

The reverberant idea and its affection are the soul of the perpetuation and of the chronicity of the painful phenomenon, responsible for its progression and refractoriness to the clinical treatment. ${ }^{17-19}$

The lesion of an unspecified medial portion of the spinothalamic and, mainly, of the spinoreticular tracts reduces the suffering sensation not directly connected to nociception through limbic modulation. ${ }^{5,20}$

Chronic pain is associated with a high degree of central and peripheral nervous system sensitization, and it is mostly expressed following neuropathic patterns. Chronicity makes the resolution prognosis rather guarded, and the reverberating component seems to be the big challenge.

The symbology of cancer-induced pain often justifies refractoriness to several treatments. Mutilation, aesthetic changes, social role reversals (from provider to provided, from caregiver to cared), future uncertainty, financial difficulties, and other situations, including acceptance of the diagnosis, interfere with the abstract portion of the suffering and with the perpetuation of pain.

The insufficient analgesic effect obtained with opioids on neuropathic pain forms suggests compliance with the poor results obtained with mesencephalotomy in predominantly neuropathic chronic pain. However, the mixed composition (neuropathic and nociceptive) of the cancer-induced pain found in most cases, and the progressive nature of the disease allow an at least partial relief with the procedure. This is also true for cordotomy, which provides total remission of pain for months, even in cases of clearly neuropathic predominance. $^{2}$

There are few surgeries with analgesic purpose that attenuate two fundamental components of pain, namely the affective and nociceptive components. Cingulotomy and mesencephalotomy are rare examples of such procedures.

Ablative techniques, such as RMM, are associated with lower costs and good analgesic effectiveness. They are economically viable, and therefore accessible to most interventional pain centers. However, the need for thorough knowledge and long training in functional neurosurgery; the risks due to surgical complications; the deterioration of the doctor-patient relationship, and the high demand levels from the part of the patients, of the their representatives, and of the legal consequences; as well as administrative interference of the hospital and funding sources; are factors that resulted in the progressive abandonment of this technique.
Less invasive methods are favored, with less associated risks, however with less effectiveness.

Ablative surgeries find a residual niche in the treatment of cancer-induced pain, ${ }^{21}$ but they are progressively abandoned due to the irreversibility of possible sequelae; in addition, although they have good effectiveness, they will always carry out cost-benefit struggles.

Mesencephalotomy has advantages over some of these procedures. Except for possible disturbances of consciousness, it can be used in patients with respiratory dysfunction, and, in selected cases, bilaterally at adequate time intervals, as a rule, unlike cordotomy. ${ }^{1}$ It addresses both the nociceptive and the reverberant components, unlike cingulotomy, which only deals with the latter.

Its performance still requires specialized centers and a staff also trained in the control of complications, including intensive care support, physical therapy, speech therapy, and orthoptics.

We note that, in our service, the postoperative survival of the patients does not match the reality of most studies. $1,2,10,20,22$ However, we believe this is due to a peculiar feature: the excellence of the concomitant care performed by the multidisciplinary group (psychologists, palliatists, neurosurgeons, physicians, nurses, physical therapists, pediatricians, and neurologists) can provide a good quality of life for a long period without the need for invasive procedures. Interventionism is only indicated when all of the conservative alternatives are exhausted.

\section{Conclusion}

Stereotactic mesencephalotomy should be performed only in cancer patients, with predominantly unilateral and above nipple level pain, including appendicular distribution and a nociceptive component. ${ }^{2}$ The new techniques of virtual image fusion reduce pathways and punctures, resulting in a lower rate of permanent complications. Its cost-effectiveness is quite attractive, and, in ideal technical conditions, it can have lower risks, rendering it a valid therapeutic option.

Conflicts of Interests

The authors have no conflicts of interests to declare.

\section{References}

1 Spiegel EA, Wycis HT. Mesencephalotomy in treatment of intractable facial pain. AMA Archives of Neurology \& Psychiatry 1953;69 (01):1-13

2 Bosch DA. Stereotactic rostral mesencephalotomy in cancer pain and deafferentation pain. A series of 40 cases with follow-up results. J Neurosurg 1991;75(05):747-751

3 Drake CG, McKenzie KG. Mesencephalic tractotomy for pain: experience with six cases. Journal of neurosurgery 1953;10 (05):457-462

4 Nashold BS Jr, Wilson WP, Slaughter DG. Sensations evoked by stimulation in the midbrain of man. J Neurosurg 1969;30(01): $14-24$

5 Lozano AM, Gildenberg PL. Tasker R. R. Textbook of Stereotactic and Functional neurosurgery. 2nd ed. Mesencephalotomy for Cancer Pain 2009;150:2532-2540 
6 Shieff C, Nashold BS Jr. Stereotactic mesencephalotomy. Neurosurg Clin N Am 1990;1(04):825-839

7 Spiller WG, Martin E. The treatment of persistent pain of organic origin in the lower part of the body by division of the anterolateral column of the spinal cord. JAMA 1912;58:1489-1490

8 Mullan S, Hekmatpanah J, Dobben G, Beckman F. Percutaneous, intramedullary cordotomy utilizing the unipolar anodal electrolytic lesion. J Neurosurg 1965;22(06):548-553

9 Oliveira JO Jr. Dor oncológica. In Coelho FRG (ed) Curso Básico de Oncologia do Hospital AC Camargo. 17:145-1641996

10 Shieff C, Nashold BS Jr. Stereotactic mesencephalic tractotomy for thalamic pain. Neurol Res 1987;9(02):101-104

11 Nashold BS Jr, Wilson WP, Slaughter DG. Stereotaxic midbrain lesions for central dysesthesia and phantom pain. Preliminary report. J Neurosurg 1969;30(02):116-126

12 Abosch A, Lozano AM. Stereotactic Ablative Procedures for Pain Relief Pain Management for the Neurosurgeon. Semin Neurosurgery $2004 ; 15$ (02. DOI: $10.1055 / \mathrm{s}-2004-835708$

13 Oliveira JO Jr, e Nogueira MN. Dor em Geriatria in Netto M P e Brito F C Urgências em geriatria 34:419-430, 2001

14 Oliveira JO Jr. Rizotomias espinhais. In: Teixeira MJ, Braun Filho JL, Marques JO, Yeng Lt (Eds). Dor contexto interdisciplinar. 14:791-7962003
15 Oliveira JO Jr. Neuroestimulação para controle da dor. In: Nitrini R Editor: Condutas em neurologia 1991-clínica neurológica HC/ FMUSP. 161-1661991

16 Weigel R, Krauss JK. Center median-parafascicular complex and pain control. Review from a neurosurgical perspective. Stereotact Funct Neurosurg 2004;82(2-3):115-126

17 Ballantine HT Jr, Cassidy WL, Flanagan NB, Marino R Jr. Stereotaxic anterior cingulotomy for neuropsychiatric illness and intractable pain. J Neurosurg 1967;26(05):488-495

18 Brown HM, Lighthill JA. Selective Anterior Cingulotomy: A Psychosurgical Evaluation. J Neurosurg 1968;29:513-519

19 Foltz EL, White LE Jr. Pain "relief" by frontal cingulumotomy. J Neurosurg 1962;19:89-100

20 Frank F, Fabrizi AP, Gaist G. Stereotactic mesencephalic tractotomy in the treatment of chronic cancer pain. Acta Neurochir (Wien) 1989;99(1-2):38-40

21 Oliveira JO Jr, Lima CHH, Serrano SC, Siões EC. A dor no doente com câncer. In: Kowalski LP, Anelli, Salvajolli, Lopes LF, editors. Manual de condutas diagnósticas e terapêuticas em oncologia. 129-147, 200220

22 Cetas JS, Saedi T, Burchiel KJ. Destructive procedures for the treatment of nonmalignant pain: a structured literature review. J Neurosurg 2008;109(03):389-404 